\title{
Effect of alkali and alkaline earth oxides on crystallization of $\mathrm{Li}_{2} \mathrm{O}-\mathrm{Al}_{2} \mathrm{O}_{3}-\mathrm{SiO}_{2}$ glasses
}

\author{
B BHOOLOKA RAO, M A JALEEL and B RAMA RAO \\ Indian Institute of Chemical Technology, Hyderabad 500007 , India \\ MS received 5 August 1988; revised 2 June 1989
}

\begin{abstract}
The effect of alkali and alkaline earth oxides on the crystallization of lithia-alumina-silica glasses has been studied. Crystallization behaviour of glasses has been investigated using DTA and XRD techniques. The principal crystallization phases are identified as $\beta$-spodumene solid solution and lithium metasilicate. The crystallization temperature of glasses decreases with increase in the values of the ionic field strength of the alkali and alkaline earth cations. Addition of these oxides at lower concentrations has no significant effect on the crystalline phases.
\end{abstract}

Keywords. Crystallization temperature; ionic field strength; lithia-alumina-silica glasses; glass ceramics; nucleating agents.

\section{Introduction}

Glass ceramics have achieved an important place in materials technology because of their unique combination of properties which has resulted in a number of engineering and other applications. Low thermal expansion crystallized glasses are becoming established in several applications where the dimensional stability and the ability to resist thermal shock are important. These materials are produced by controlled crystallization of glasses and have properties superior to those of the parent glasses. Preparation of glass ceramics consists of making a homogeneous glass, shaping it to the desired form and finally heat-treating it to produce a glass ceramic body. These are free from pores. Absence of pores imparts higher mechanical strength (McMillan 1979). Glass ceramic bodies in various shapes and with close dimensional tolerances can be produced by commercial methods. In recent years several studies on nucleation and crystallization behaviour of glasses (Stookey 1961; MacDowell 1966; Patridge 1982) have been carried out. The study of the crystallization of glasses has significant importance both scientifically and technologically.

The glass forming system, lithia-alumina-silica, for producing glass ceramics has been studied by many authors (Patridge and McMillan 1963; Samdani et al 1969; Rapp 1973). In this system the crystallization is effected easily and a low thermal expansion phase is also formed. Preparation of a satisfactory glass ceramic depends on crystallizing the desirable phases under controlled conditions to provide a fine microstructure. Although major work has been carried out on various nucleating agents (Zdaniewski 1975; Barry et al 1970) and their behaviour on crystallization, no studies on crystallization with alkali and alkaline earth oxides have been carried out. Hence the present work was undertaken.

\section{Experimental}

The specimens used in this study were prepared by using reagent (LR) quality materials 
(table 1), mixed thoroughly and melted in a sillimanite crucible at $1450^{\circ} \mathrm{C}$ for $2 \mathrm{~h}$ in an electric muffle furnace under normal atmospheric conditions. The molten glass was cast in the form of discs on steel plates and was allowed to cool rapidly in air. The specimens were not annealed because thermal history effects are minimized. Heat treatment was carried out at $550^{\circ} \mathrm{C}$ for $2 \mathrm{~h}$ followed by $750^{\circ} \mathrm{C}$ for $1 \mathrm{~h}$ at a rate of $5^{\circ} \mathrm{C} / \mathrm{min}$ and was furnace-cooled.

Differential thermal analysis (DTA) was carried out on powdered glass on a Leeds and Northrup instrument. Calcined alumina was used as the inert material and the rate of heating was $12.5^{\circ} \mathrm{C} / \mathrm{min}$. The crystallized glass powders were subjected to X-ray diffraction analysis (XRD) for the identification of phases formed during crystallization. A Phillips X-ray diffractometer (PW 1051) was used.

\section{Results and discussion}

Glasses containing $\mathrm{TiO}_{2}$ are light yellow in colour whereas those containing $\mathrm{ZrO}_{2}$ and $\mathrm{P}_{2} \mathrm{O}_{5}$ are colourless. The progress of crystallization is marked by the changes in the appearance of the material. All the glasses become opaque and white during crystallization. Crystallization of glasses is followed by exothermic peaks as recorded in DTA. Table 2 summarises these results along with the phases identified by XRD and field strength of oxides for different nucleating agents. The peaks in figures $1-4$ show DTA and XRD patterns respectively. It can be seen that $\mathrm{TiO}_{2}$ and

Table 1. Glass ceramic-compositions (wt. \%).

\begin{tabular}{lccccc}
\hline & \multicolumn{5}{c}{ Batch numbers } \\
\cline { 2 - 6 } Constituent & 1 & 2 & 3 & 4 & 5 \\
\hline $\mathrm{SiO}_{2}$ & $66 \cdot 50$ & $66 \cdot 50$ & $66 \cdot 50$ & $66 \cdot 50$ & $66 \cdot 50$ \\
$\mathrm{Al}_{2} \mathrm{O}_{3}$ & $13 \cdot 70$ & $13 \cdot 70$ & $13 \cdot 70$ & $13 \cdot 70$ & $13 \cdot 70$ \\
$\mathrm{LiO}_{2}$ & $16 \cdot 80$ & $16 \cdot 80$ & $16 \cdot 80$ & $16 \cdot 80$ & $16 \cdot 80$ \\
$\mathrm{Na}_{2} \mathrm{O}$ & $2 \cdot 00$ & - & - & - & - \\
$\mathrm{CaO}$ & - & $2 \cdot 00$ & - & - & - \\
$\mathrm{BaO}$ & - & - & $2 \cdot 00$ & - & - \\
$\mathrm{MgO}$ & - & - & - & $2 \cdot 00$ & - \\
$\mathrm{K}_{2} \mathrm{O}$ & - & - & - & - & $2 \cdot 00$ \\
\hline
\end{tabular}

In each batch 3 wt. \% each nucleating agents $\left(\mathrm{TiO}_{2}, \mathrm{ZrO}_{2}\right.$ and $\left.\mathrm{P}_{2} \mathrm{O}_{5}\right)$ were added.

Table 2. Crystallization temperature $\left({ }^{\circ} \mathrm{C}\right)$ of the glasses (DTA).

\begin{tabular}{|c|c|c|c|c|c|}
\hline \multirow[b]{2}{*}{ Oxides } & \multicolumn{3}{|c|}{ Nucleating agents } & \multirow{2}{*}{$\begin{array}{c}\text { Field } \\
\text { strength } \\
\left(Z / r^{2}\right)^{*}\end{array}$} & \multirow{2}{*}{$\begin{array}{c}\text { Crystalline } \\
\text { phases (XRD) }\end{array}$} \\
\hline & $\mathrm{TiO}_{2}$ & $\mathrm{ZrO}_{2}$ & $\mathrm{P}_{2} \mathrm{O}_{5}$ & & \\
\hline $\mathrm{Na}_{2} \mathrm{O}$ & 610 & 705 & 570 & 1.04 & $\begin{array}{l}\beta \text {-Spodumene and } \\
\text { lithium meta } \\
\text { silicate }\end{array}$ \\
\hline $\mathrm{K}_{2} \mathrm{O}$ & 630 & 710 & 580 & 0.57 & - do \\
\hline $\mathrm{MgO}$ & 615 & 675 & 570 & $3 \cdot 29$ & do- \\
\hline $\mathrm{CaO}$ & 630 & 680 & 630 & 1.79 & - do- \\
\hline $\mathrm{BaO}$ & 645 & 665 & 555 & 0.98 & - do- \\
\hline
\end{tabular}

*Based on Pauling's ionic radius. 


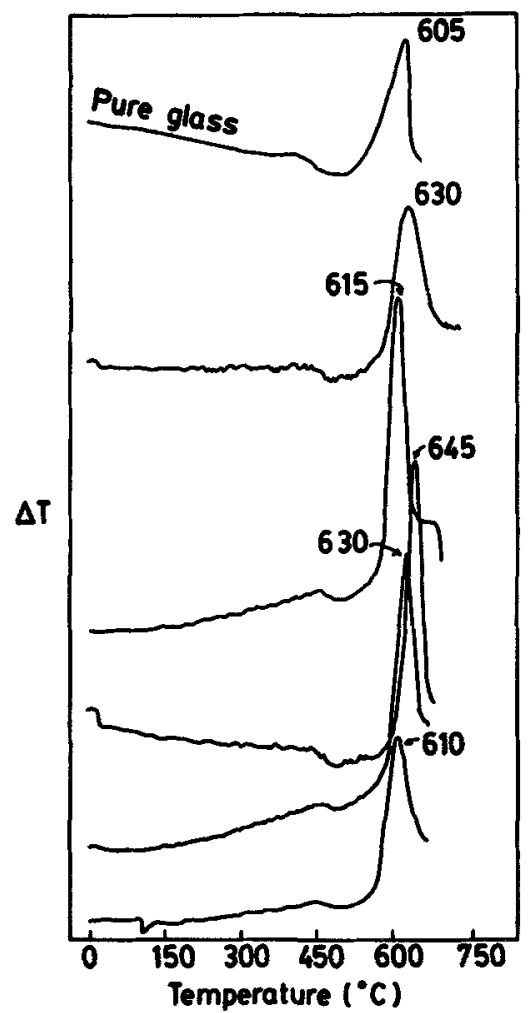

Figure 1. DTA curves of $\mathrm{TiO}_{2}$ nucleated glasses.

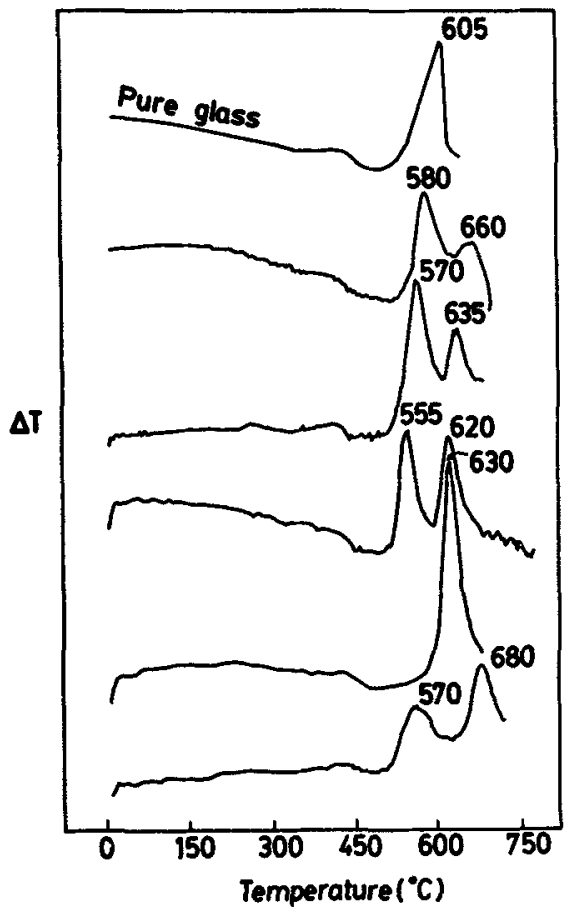

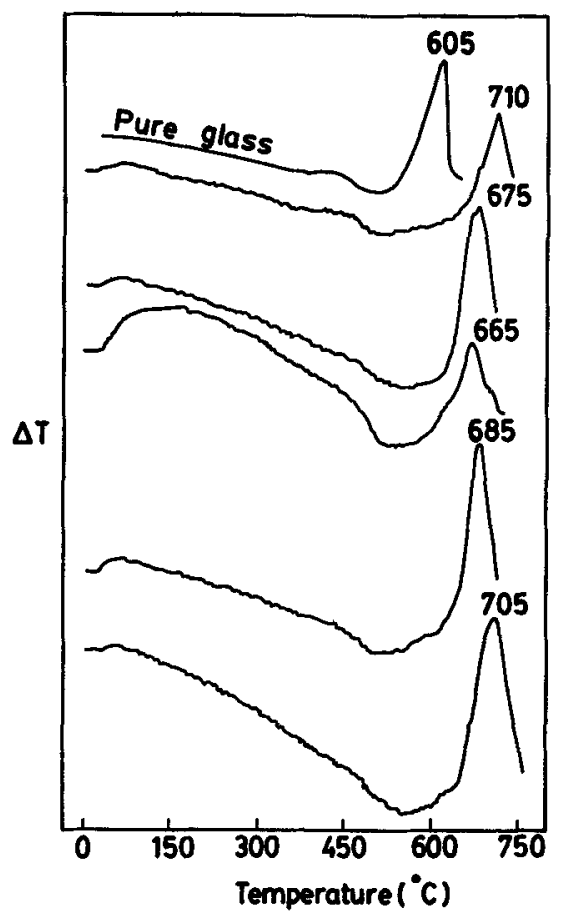

Figure 2. DTA curves of $\mathrm{ZrO}_{2}$ nucleated glasses.

Figure 3. DTA curves of $\mathrm{P}_{2} \mathrm{O}_{5}$ nucleated glasses. 


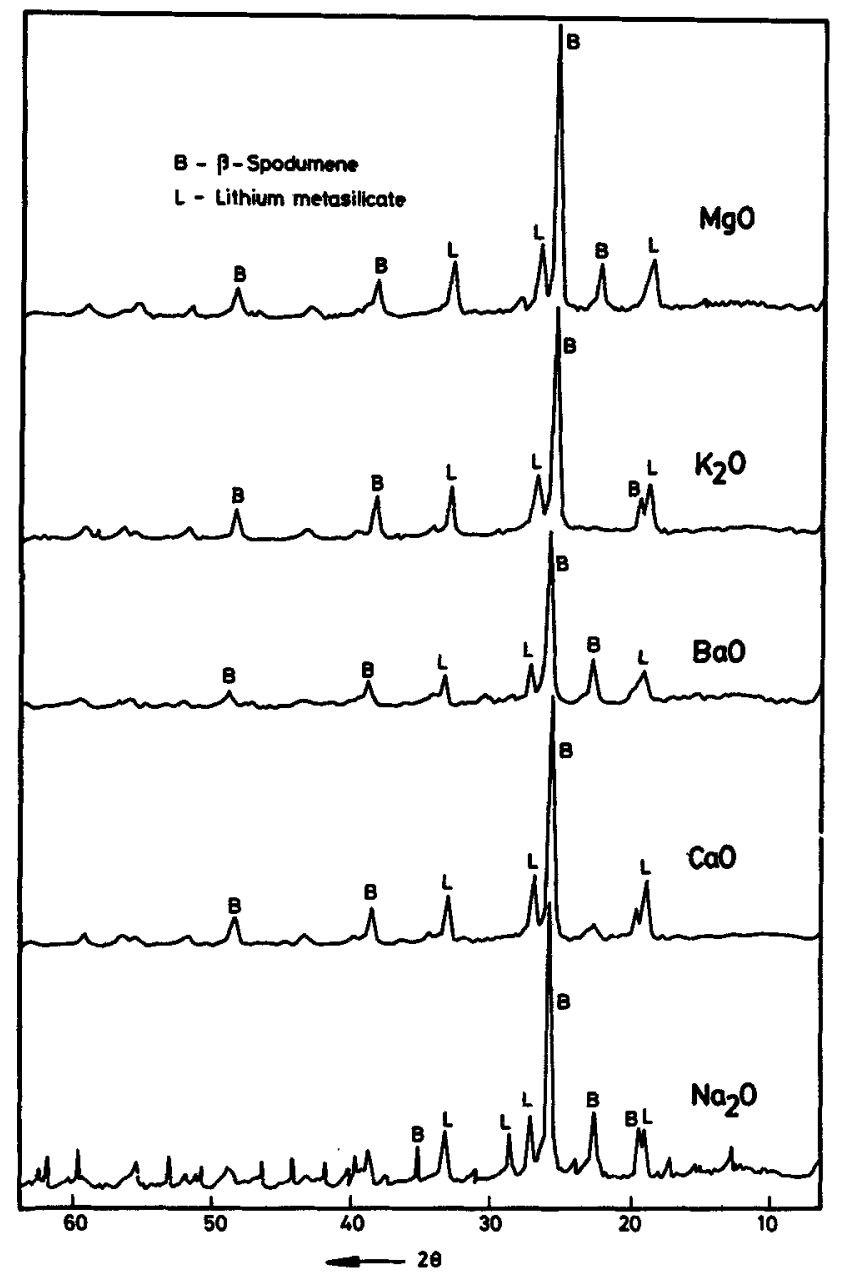

Figure 4. XRD patterns for crystallized glasses.

$\mathrm{ZrO}_{2}$ nucleated glasses crystallized at higher temperatures as compared to $\mathrm{P}_{2} \mathrm{O}_{5}$ nucleated glasses. This could be due to the glass-forming nature of $\mathrm{P}_{2} \mathrm{O}_{5}$ and its ability to induce phase separation at lower temperatures. Phase-separation in the glass may be due to the charge difference between the principal glass networkforming ions, $\mathrm{Si}^{4+}$ and the foreign network-forming ions, $\mathrm{P}^{5+}$. Pure glass crystallizes at $605^{\circ} \mathrm{C}$. Addition of alkali and alkaline earth oxides has thus changed the crystallization temperature of glasses.

An interesting observation as indicated in table 2 is the effect of the ionic field strength of the alkali and alkaline earth cations on the crystallization temperature. The crystallization temperature of glasses in general decreases with higher values of field strength. This could be due to the fact that the cations of higher field strength can facilitate crystallization in glasses. X-ray patterns, shown in figure 4, for glasses crystallized at $550^{\circ} \mathrm{C}$ followed by $750^{\circ} \mathrm{C}$ are almost the same. These analyses reveal that the principal crystalline phases appearing for all the oxides are the $B$ - 
spodumene $\left(\mathrm{Li}_{2} \mathrm{Al}_{2} \mathrm{Si}_{4} \mathrm{O}_{12}\right)$ solid solution and lithium metasilicate $\left(\mathrm{Li}_{2} \mathrm{SiO}_{3}\right)$. Addition of these oxides has no significant effect on the crystallized phases.

\section{Conclusion}

Crystallization temperatures of lithia-alumina-silica glasses decrease with increase in the values of field strength of the alkali and alkaline earth oxides. Addition of these oxides in lower concentrations has no significant effect. on the crystalline phases.

\section{Acknowledgements}

The authors are thankful to Prof S G Samdani, College of Technology, Osmania University, for useful discussions.

\section{References}

Barry T I, Lay L A and Miller R P 1970 Discuss. Faraday Soc. 5214

MacDowell J F 1966 Ind. Eng. Chem. 5845

McMillan P W 1979 Glass ceramics (London: Academic Press) pp 158

Patridge G 1982 Glass Technol. 23133

Patridge G and McMillan P W 1963 Glass Technol. 64

Rapp J E 1973 Ceram. Bull. 526

Samdani S G, Prasad V M and Abid Ali 1969 Trans. Indian Ceram. Soc. 19

Stookey S D 1961 Chem. Eng. News 39116

Zdaniewski W J 1975 Am. Ceram. Soc. 58163 